\title{
Feasibility Study Designing Electric Motorcycles with Fossil Fuels Compared to Hybrid Systems on 150cc Motorcycles
}

\author{
Pawenary ${ }^{1}$, Septianissa Azzahra ${ }^{1}$, Hastuti Azis ${ }^{1}$, Anton Satria Prabuwono ${ }^{2}$ \\ ${ }^{1}$ Electrical Technology Study Program, Faculty of Electricity and Renewable Energy, PLN Institute of Technology, Jakarta, Indonesia \\ ${ }^{2}$ Rabigh Faculty of Computer and Information Technology (FCITR), King Abdulaziz University, Saudi Arabia
}

\section{ARTICLE INFORMATION}

Received: April, 29, 2021

Revised: June 19, 2021

Available online: July 2, 2021

\begin{tabular}{l} 
KEYWORDS \\
\hline Transformation, Feasibility Study, Electric \\
Motorcycle 150cc, Hybrid system. \\
CORRESPONDENCE \\
\hline Phone: +62 811-1895-202 \\
E-mail: pawenary@itpln.ac.id \\
\hline
\end{tabular}

\begin{abstract}
A $\quad$ B $\quad S \quad T \quad R$ A $\mathbf{C}$ T
In this study, an electric vehicle was designed using fossil fuels compared to the hybrid system on a 150cc motorcycle. The design of electric motorcycle vehicles focuses on knowing the feasibility study comparison between engine drive and electrical drive. In the design of electric motorcycle vehicles, know how to make technical-economic calculations on electric motorcycles. And converting energy from mechanical energy into electric energy or vice versa requires a device called an electric motor. Having the knowledge and experience in the manufacture of electric motors will be more helpful and become important in the future. Electric vehicles are the solution to depleting petroleum reserves and pollution problems that increase each year due to exhaust emissions produced by oil-fueled vehicles. The contribution of motor vehicle exhaust as a source of air pollution reaches $60-70 \%$. The decline of fossil fuels in the world is also a significant problem that is currently unresolved. The analytical technique used in this study is a descriptive statistic technique. This study will be assessed the technical data that occurs on the calculation of the speed of what motor is by the specified standards.
\end{abstract}

\section{INTRODUCTION}

Transportation is an important means of supporting development, especially in supporting the community's economic activities to meet the needs of daily goods and services and improve socioeconomic life quality [1]-[3].

The uncontrolled growth of vehicle populations is the cause of increasing demand for energy by consumers and results in air pollution resulting from vehicle exhaust emissions[4]-[6].

From the Environmental Management Agency (BPLDH) data from various sectors that can pollute the air, in general, the transportation sector plays a very large role compared to other sectors. In major cities, motor vehicle exhaust gas contribution as a source of air pollution reaches $60-70 \%$ [7],[8]. There has been a lot of research on motorcycles, such as the technical aspects[9].

The electric vehicle is a solution to depleting petroleum reserves and pollution problems that increase every year due to exhaust emissions produced by oil-fueled vehicles [10], [11].

From the problem state above, the author tried to design a concept of two-wheeled, three-wheeled, or four-wheeled vehicles with two or more passengers using the VDI method (Verein Deutscher https://doi.org/10.25077jnte.v10n2.906.2021
Ingenieur) [12] with a focus on designing the design of the shape and dimensions of a sleek vehicle by using an electric motor that is appropriate so that this electric vehicle can work optimally, efficiently and environmentally friendly. The most dominant modification of this electric vehicle is on its drive; the old drive uses the engine, while the new drive uses an electric motor named BLDC; researchers have widely used BLDC as a drive because it uses an electric motor [13]-[19].

The purpose of the research is to know the feasibility study comparison between engine drive with electrical drive, know how to design an electric motorcycle without fossil energy, and know how to make technical-economic calculations on electric motorcycles.

\section{BLDC MOTOR}

\section{BLDC Electric Motor}

A BLDC electric motor is a motor whose magnetic field generation uses a permanent magnetic material located on the rotor. The brushless D.C. motor is almost the same as the synchronous A.C. motor. The main difference is if the synchronous A.C. motor generates sinusoidal reverse EMF 
waves, while the brushless D.C. motor produces box-turning EMF waves or trapezoids. The equation between a synchronous A.C. motor and another brushless D.C. motor is that both will form a magnetic field spin that generates torque on the magnetic rotor.

Here are the types of BLDC electric motors:

\section{Exterior Rotor}

An exterior-rotor type BLDC motor is a motor whose rotor or rotating part is the outside. This type of motor has good efficiency and a generally more straightforward wrapping process.

2. Interior Rotor

The interior-rotor type BLDC motor is a motor with a rotor part that is a rotating part, located inside the circle of the stator, which is the silent part. In general, this type of motor is designed for applications that require large torque and can perform acceleration and deceleration with good response.

3. Axial-Gap

Axial-gap type BLDC motor is a motor with rotor parts and stators piled up. The main advantage of the axial-gap motor is that it does not have cogging torque because it does not have a slot on its stator. In general, this motor is designed for applications that require low and constant speed.

\section{Material Motor BLDC}

The materials required for BLDC motors are materials for permanent magnets, core materials, and conductor wire materials.

\section{Permanent Magnet}

Permanent magnetic material is a material that can produce a magnetic field without having to use excitation.

2. B-H curve

If material is given a magnetic intensity $(\mathrm{H})$ with a positive value, then the magnetic flux density (B) increases until it reaches the saturation value.

3. Permanent Magnet on BLDC Motor

Some materials used as permanent magnetic materials are alnicos ( $\mathrm{Al}, \mathrm{Ni}, \mathrm{Co}, \mathrm{Fe})$, ferrites, and rare-earth materials.

4. Core Material

Bldc motor core material uses soft magnet material, a material with a narrow hysteresis curve, low coercivity, and high permeability.

5. Inductor Wire Material

Copper material is the most widely used material as a conductor material in electrical machinery.

\section{Electromagnetic on BLDC Motor}

Flux in BLDC is sourced from permanent magnets on the rotor. Flux plays an essential role in the speed and torque parameters of the motor. Stator acts as a flux guide that transmits flux movement. Flux on the motor is intended to connect with the coil on the stator. The flux that moves from the positive pole to the negative pole but without passing through the coil as it should be is called leakage. Flux leakage is a flux from the rotor pole that moves towards the air to move towards the coil. While fringing is flux should follow the path flux guide or core, precisely out of the path to the air.

\section{Power/Battery Storage}

Batteries are electrical-chemical devices that serve to store energy and expend power in the form of electricity. Usually, electric motors use a lithium battery that produces high energy power and is safe in its use.

\section{METHOD}

Research Design in this research consists of two steps:

1. Task description

In this stage, the author tries to gather information from various sources by sharing questionnaires with 20 respondents. The results of the respondents are then calculated to then describe them as clearly as possible in the requirement list and identify the obstacles faced to achieve the optimal solution.

2. Concept Design

The results of the analysis of the list of needs above are produced abstraction steps in determining the main problems in the design of electric vehicles, namely: Ignoring personal desires or wishes (wishes) that have no direct effect on the functions and constraints that are important in the design of electric vehicle concepts.

The analysis technique used in this study is a descriptive statistic. In this study, an assessment of the technical data in motor speed calculation is by the specified standards.

\section{RESULTS AND DISCUSSION}

\section{BLDC Motor Design}

This section will be discussed the results and discussion of research by discussing the design, specifications, and testing conducted on BLDC motors.

\section{BLDC Motor Design and Sketch}

The initial stage of this research is to design a BLDC electric motor. BLDC motors work for the main source of electric motorcycle propulsion where the driving source is a DC battery which is raised to AC through an inverter. The design and BLDC motorcycle sketches can be seen in Figure 1 .

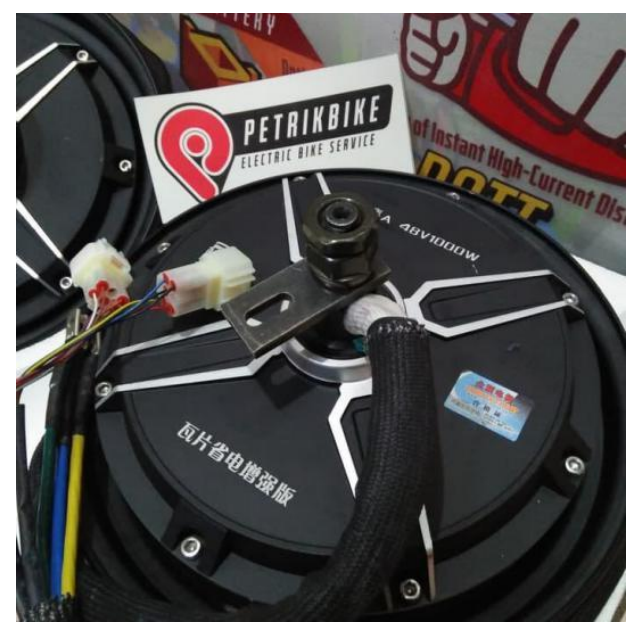

Figure 1. BLDC Motor Design and Sketch

https://doi.org/10.25077/jnte.v10n2.906.2021 


\section{BLDC Motor Drawing}

After obtaining the BLDC draft, the next step is to design the motor. A series of BLDC motorcycle designs that function to adjust the body frame on a motorcycle. Here is a drawing of the BLDC motor, as can be seen in Figure 2.

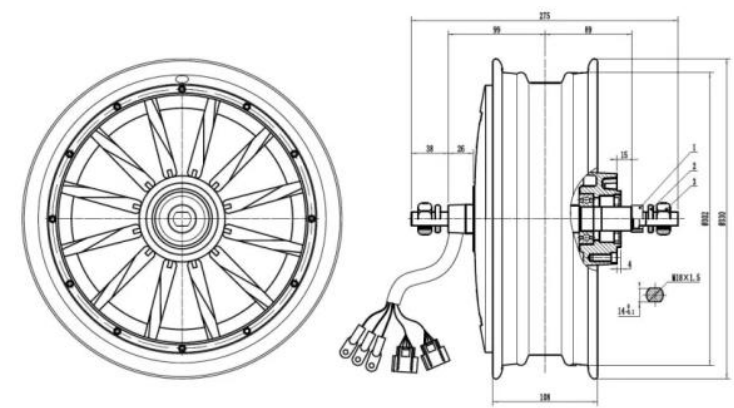

Figure 2. Drawing Motor BLDC

\section{BLDC Motor Specifications}

Here are the specifications of BLDC motorcycles:

Motor Type $\quad$ : BLDC Outer Rotor In-Wheel Hub Motor with Hall Sensor

Brand : QS Motor,QSMOTOR

Motor Design $\quad$ : Double axle with 10inch moped rim (integrated)

Rim size $\quad: 10 \times 2.15$ inch (Narrow Tire as default),

Matched tire $\quad: 3.0-10,3.5-10$ etc $10 \times 3.0$ inch (Wide Tire)

Magnet Height $\quad: 55 \mathrm{~mm}, 16$ pole pairs

Stator : Aluminum Core

Rated Power : $3000 \mathrm{~W}$

Speed : $707 \mathrm{Rpm}$

Max Torque : Approx. $174 \mathrm{Nm}$

KV $\quad: 14.7$

Max Efficiency : Approx. 91\%

Brake Type : Disc brake (default as), PCD3*80mm-M8, C.B. $58 \mathrm{~mm}$

Drop-outs : $\quad 200 \mathrm{~mm}$

Dual Halls with waterproof connectors (One for spare, in case of damage)

$10 \mathrm{~mm}^{2}$ Phase Wire

Waterproof Grade : I.P. 54

Color : Black (as default)

\section{Phase Inverter Circuit}

The next stage in this design requires a 3-phase $\mathrm{DC}$ to $\mathrm{AC}$ rectifire diode circuit. it is used to convert DC voltage into AC voltage. Here is a series of 3 phase inverters that can be seen in Figure 3.

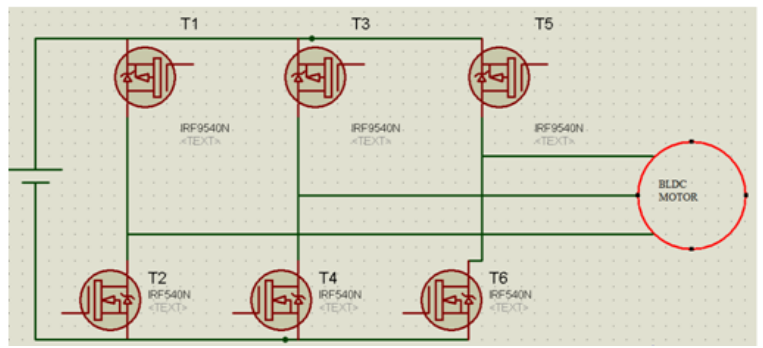

Figure 3. 3 Phase Inverter Circuit

\section{Throttle}

Throttle is a potentiometer as a variable DC source so that the DC source can be adjusted to the size of the inverter. It's like a replacement for hand gas on an ordinary motorcycle. Figure below is the throttle image that can be seen in Figure 4.

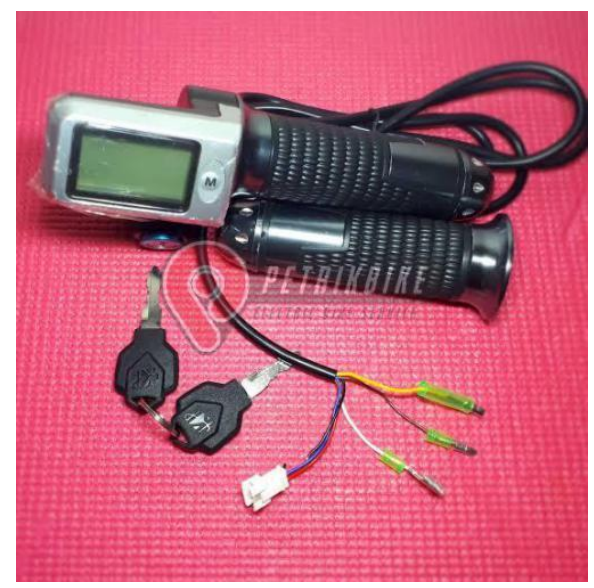

Figure 4. Throttle

\section{Electrical Installation of BLDC Motor}

The electrical installation of the BLDC motor is designed and installed in accordance with the planned installation, starting from calculating battery requirements, designing the size of the inverter and controller. Design according to motor power requirements. The electrical installation of the bldc motor can be seen in Figure 5.

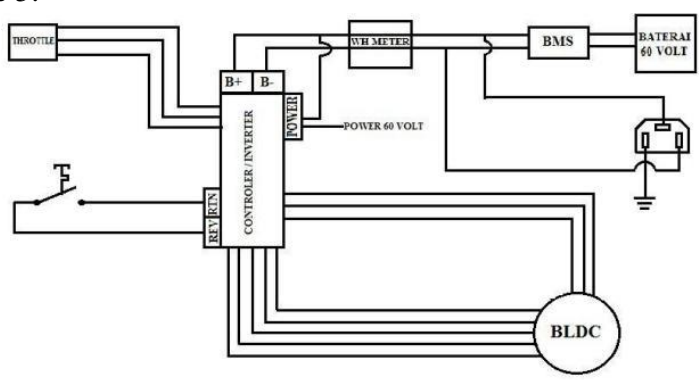

Figure 5. Electrical Installation of BLDC Motor

\section{Battery Installation}

A series of parallel series battery preparation where per 2.6 Volt DC battery is stacked to produce 60 Volt DC as needed. The battery installation can be seen in Figure 6 .

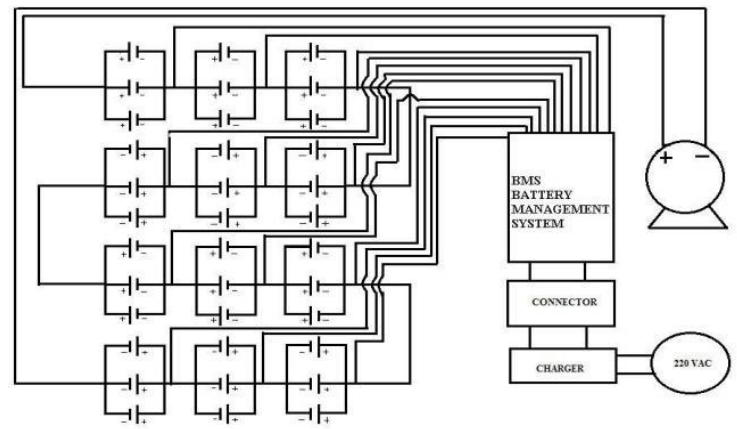

Figure 6. Battery Installation 


\section{Electric Vehicle Frame and Chassis Design}

Before carrying out the test, it is necessary to design the vehicle frame and chassis. where it is used to design the size and specifications of the body that adjusts the load, passenger weight, goods weight, and others. The vehicle frame and chassis design can be seen in Figure 7 and Figure 8.

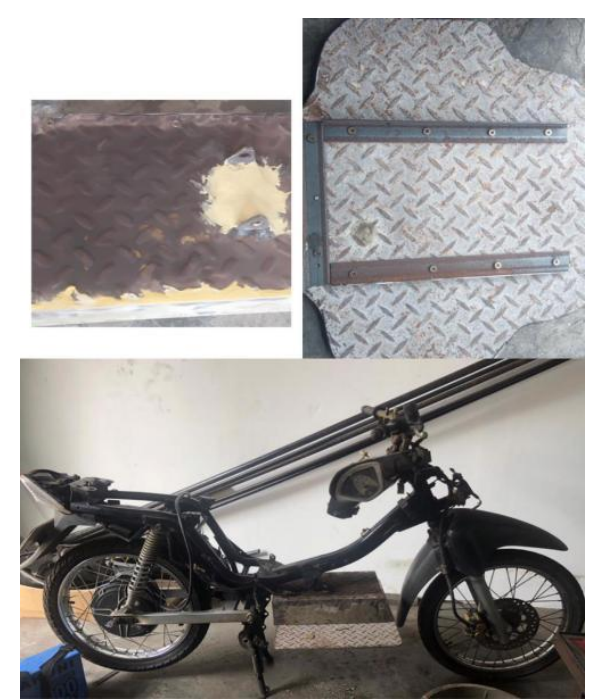

Figure 7. Electric Vehicle Frame and Chassis Design

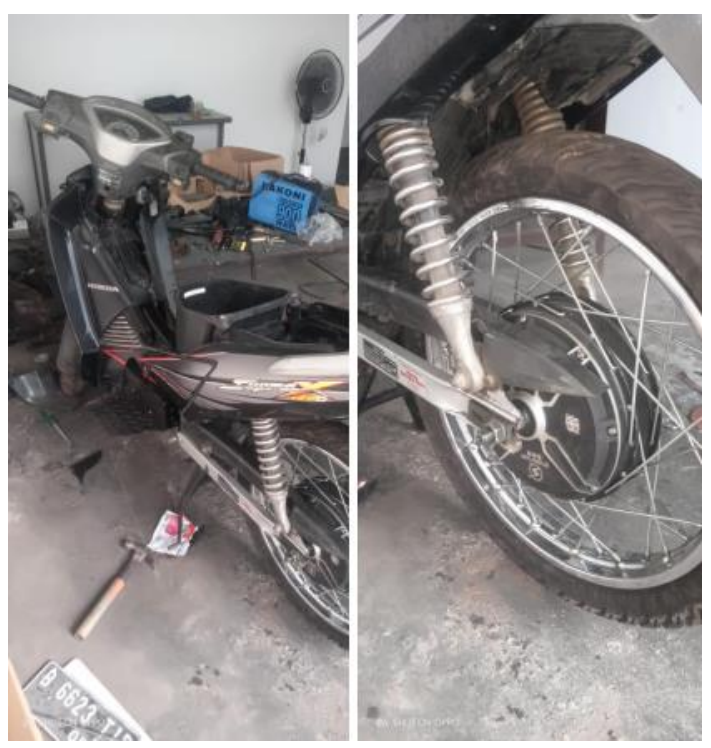

Figure 8 . BLDC body and motor design

\section{BLDC Motor Testing}

This section will be delivered BLDC Motor tests. It is starting from the initial testing stage until the final stage of testing. The testing we can seen from the appendix. Table 1 showed the test variables that used in this research. This variables used for testing the BLDC motors.

Table 1. Test Variables

\begin{tabular}{ccc}
\hline No & Test Variables & Description \\
\hline 1 & Battery & $50 \mathrm{Ah}$ \\
2 & Voltage $3 \varphi$ & $60 \mathrm{~V}$ \\
3 & Speed BLDC & $80 \mathrm{Km} /$ Hour \\
4 & Power Hood & $3 \mathrm{Kw}$ \\
\hline
\end{tabular}

\section{LoadLess Testing}

The next stage in this research is the testing stage. Where in this stage it is carried out with two scenarios, namely no-load and using load. Table 2 showed the results of the motorcycle wiithout load. Table 2 is a motorcycle trial speed measurement of the voltage and current used compared to the efficiency of the motor and the length of battery life (no load).

Table 2. Test Results Without Load

\begin{tabular}{cccccc}
\hline $\begin{array}{c}\text { Speed } \\
(\mathrm{Km} / \mathrm{H})\end{array}$ & $\begin{array}{c}\text { Voltage } \\
(\mathrm{V})\end{array}$ & $\begin{array}{c}\text { Current } \\
(\mathrm{A})\end{array}$ & $\begin{array}{c}\text { Motor } \\
\text { Efficiency } \\
(\%)\end{array}$ & $\begin{array}{c}\text { Battery } \\
\text { Life } \\
(\text { Minutes })\end{array}$ & Description \\
\hline 33 & 58.39 & 25.3 & 49.2 & 157 & Efficiency \\
41 & 58.51 & 30.9 & 60.2 & 154 & obtained: \\
52 & 57.76 & 41 & 78.8 & 106 & P out / P in \\
61 & 55.94 & 49 & 91.3 & 82 & \\
\hline
\end{tabular}

\section{Load Testing}

Table 3 showed that the test results with loads with driver and 1 passenger.

Table 3. Load Test Results

\begin{tabular}{cccccc}
\hline $\begin{array}{c}\text { Speed } \\
(\mathrm{Km} / \mathrm{H})\end{array}$ & $\begin{array}{c}\text { Load } \\
(\mathrm{Kg})\end{array}$ & $\begin{array}{c}\text { Voltage } \\
(\mathrm{V})\end{array}$ & $\begin{array}{c}\text { Current } \\
(\mathrm{A})\end{array}$ & $\begin{array}{c}\text { Battery } \\
\text { Life } \\
\text { (Minutes) }\end{array}$ & $\begin{array}{c}\text { Motor Driver } \\
\text { Efficiency }+1 \\
\text { Passenger }(\%)\end{array}$ \\
\hline 10 & 240 & 58.39 & 25.3 & 157 & 53.16 \\
20 & 240 & 58.51 & 30.9 & 154 & 64.4 \\
30 & 240 & 57.76 & 41 & 106 & 85.2 \\
40 & 240 & 55.94 & 49 & 82 & \\
\hline
\end{tabular}

\section{Battery Charging Testing}

Here are the battery charging test results that can be seen in Table 4.

Table 4. Battery Charging Test Results

\begin{tabular}{ccc}
\hline No & Time (Minutes) & $\begin{array}{c}\text { Battery } \\
\text { Capacity (Ah) }\end{array}$ \\
\hline 1 & 30 & 10 \\
2 & 60 & 20 \\
3 & 90 & 30 \\
4 & 120 & 40 \\
\hline
\end{tabular}

\section{Cost Comparison Analysis}

Cost comparison analysis was conducted by comparing the cost between vehicles using BLDC motors with gasoline. Table 5 showed the results of cost analysis using BLDC motor while Table 6 showed the results of cost analysis using gasoline fuel.

\begin{tabular}{cccc}
\multicolumn{4}{c}{ Table 5. Cost Analysis Results Using BLDC Motor } \\
\hline No & $\begin{array}{c}\text { Distance } \\
(\mathrm{Km})\end{array}$ & $\begin{array}{c}\text { Time } \\
\text { (Minutes) }\end{array}$ & Cost (Rp) \\
\hline 1 & 1 & 5 & 33,8 \\
2 & 2 & 10 & 67,6 \\
3 & 3 & 13 & 81,12 \\
4 & 4 & 25 & 101,4 \\
5 & 5 & 30 & 135,2 \\
\hline
\end{tabular}


Table 6. Cost Analysis Results using Gasoline

\begin{tabular}{ccccc}
\hline No. & Distance $(\mathrm{Km})$ & $\begin{array}{c}\text { Time } \\
\text { (Minutes) }\end{array}$ & $\begin{array}{c}\text { Gasoline } \\
\text { (Liters) }\end{array}$ & $\begin{array}{c}\text { Cost } \\
(\mathrm{Rp})\end{array}$ \\
\hline 1 & 1 & 3 & 1 & 7650 \\
2 & 2 & 5 & 1.5 & 11475 \\
3 & 3 & 9 & 2.2 & 16830 \\
4 & 4 & 13 & 3 & 22950 \\
5 & 5 & 17 & 4 & 30600 \\
\hline
\end{tabular}

From tables 5 and 6 above, it can be seen that the time efficiency for comparison by using a BLDC motor and engine fuel is much more efficient by $43.3 \%$. while the cost if using fuel, is very expensive up to $213 \%$.

\section{Financial Aspects Analysis}

The following analysis of the financial aspects of motorcycles is determined by calculating NPV, IRR, PPB, and BCR.

Table 7. Financial Aspects Analysis

\begin{tabular}{cc}
\hline Rate & $12 \%$ \\
\hline NPV & $494.048 .977 .010,99$ \\
IRR & $22 \%$ \\
PBP & 3.14 Years Old \\
BCR & 82,96 \\
\hline
\end{tabular}

Based on Table 7, it can be known that in calculating financial aspects analysis of motorcycles, net present value (NPV) is obtained at Rp. 494,048,977,010.99. This NPV value helps measure investment opportunities and see if the investment is worth doing or not. In Table 7, the value of NPV is positive so that the investment is worth doing.

Then, the table also obtained an internal rate of return (IRR) value of $22 \%$. This means that the efficiency level of the investment is worth $22 \%$. Then, in Table 7, the Payback Period (PBP) value is known for 3.14 years. This means that the period of return on capital is 3.14 years. Furthermore, there is a BCR value to analyze the financial aspect, which has a value of 82.96 . The significant BCR value of 1 indicates that the benefits of the project outweigh the sacrifices incurred so that the project can be accepted or feasible.

\section{CONCLUSIONS}

The results showed that the cost of using BLDC motors is cheaper compared to gasoline. The time efficiency for comparison by using a BLDC motor and engine fuel is much more efficient by $43.3 \%$ while the cost if using fuel, is very expensive up to $213 \%$.

\section{ACKNOWLEDGMENT}

The thank you goes to the Faculty of Electricity and Renewable Energy, who have financed the research.

\section{REFERENCES}

[1] "COMPARATIVE ANALYSIS OF EXTRINSIC AND INSTRINSIC MOTIVATION BETWEEN GOJEK DRIVER AND GRAB DRIVER IN MANADO," J. EMBA J. RIS. Ekon. Management, Business and Accounting. , vol. 6, no. 4, 2018, doi: 10.35794/emba.v6i4.21058.

[2] K. Biomantara and H. Herdiansyah, "The Role of Indonesian Railways (KAI) as Urban Area Transportation Infrastructure," J. Hum. Bina Sarana Inform. Horizon, vol. 19, no. $1,2019$.

[3] A. A. Purwati and M. L. Hamzah, "Total service quality management and it's impact on customer satisfaction and loyalty of online transportation in Indonesia," Int. J. Sci. Technol. Res. , vol. 8, no. 11, 2019.

[4] L. A. P.F. De Brito, J.B. Carvalho, and V. D. Toledo, "The efficiency of mathematical algorithms for urban noise evaluation," Urbe, vol. 10, no. 1, 2018, doi: 10.1590/21753369.010.001.AO03ISSN2175-3369.

[5] M. Razban and H. I. Talab, "Designing bandar abbas railway station by sustainable architecture approach (Climatic sustainability)," IIOAB J. , vol. 7, 2016.

[6] H. Chang, Y. Wang, Z. Li, B. Lin, Z. Song, and J. Tan, "Regional ecological risk assessment based on nitrogen export: A case study in Chinese Taiwan," Shengtai Xuebao/ Acta Ecol. Sin. , vol. 36, no. 4, 2016, doi: $10.5846 / \mathrm{stxb} 201406031144$.

[7] M. Panayotova, "The motor vehicles - A significant cause for air pollution in the big towns of Bulgaria," J. Environ. Sci. Heal. - Part A Toxic/Hazardous Subst. Environ. Eng. , vol. 31, no. 1, 1996, doi: 10.1080/10934529609376349.

[8] P. Podesser, "Unlimited cruising range - How fuel cells empower electric vehicles," in Electric Drive Transportation Association - 23rd Int. Electric Vehicle Symposium and Exposition 2007, EVS 2007 (Battery, Hybrid, Fuel Cell) Conf. Proc. - Sustainability: The Future of Transportation, 2007, vol. 2.

[9] M. Latif, A. Valdesio, and M. Muharam, "Electrical Energy from Motorcycle Regenerative Braking using Bicycle Dynamo," J. Nas. Tech. ELEKTRO, vol. 7, no. 2, 2018, doi: 10.25077/jnte.v7n2.503.2018.

[10] G. Jungmeier, The Biorefinery Fact Sheet,vol. 23, no. 1. 2017.

[11] S. S.M, G. S. Tantri, M.M. J, V. Ch, G. G. L, and V. kumar G. Naik, "Intelligent Solar Tracker Vehicle for Supply Channel of Electric Vehicle Need Using Image Processing and Mobile Network," Int. J. Innov. Sci. Res. Technol. , vol. 5, no. 6, 2020, doi: 10.38124/ijisrt20jun1126.

[12] F. Maulana, "ECO-FRIENDLY THREE-WHEELED ELECTRIC VEHICLE DESIGN CONCEPT," Maj. Ilm. Pengkaj. Ind. , vol. 10, no. 2, 2018, doi: 10.29122/mipi.v10i2.141.

[13] Y. Park, H. Kim, H. Jang, S. H. Ham, J. Lee, and D. H. Jung, "Efficiency Improvement of Permanent Magnet BLDC with Halbach Magnet Array for Drone," IEEE Trans. Appl. Supercond. , vol. 30, no. 4, 2020, doi: 10.1109/TASC.2020.2971672. 
[14] D. S. Nayak and R. Shivarudraswamy, "Solar fed BLDC motor drive for mixer grinder using a boost converter," Int. A. Power Electron. Syst Drive. , vol. 11, no. 1, 2020, doi: 10.11591/ijpeds.v11.i1.pp56-63.

[15] M. Mahmud, S.M. A. Motakabber, A. H.M. Z. Alam, and A. N. Nordin, "Control BLDC motor speed using PID controller," Int. A. Adv. Comput. Sci. Appl. , vol. 11, no. 3, 2020, doi: 10.14569/ijacsa.2020.0110359.

[16] D. Potnuru, K. Alice Mary, and C. Sai Babu, "Experimental implementation of Flower Pollination Algorithm for speed controller of a BLDC motor," Ain Shams Engineering Journal, vol. 10, no. 2. 2019, doi: 10.1016/j.asej.2018.07.005.

[17] K. Kolano, "Improved sensor control method for BLDC motors," IEEE Access, vol. 7, 2019, doi: 10.1109/ACCESS.2019.2960580.

[18] M. S. Trivedi and R. K. Keshri, "Evaluation of Predictive Current Control Techniques for PM BLDC Motor in Stationary Plane," IEEE Access, vol. 8, 2020, doi: 10.1109/ACCESS.2020.2978695.

[19] D. Kumpanya, S. Thaiparnat, and D. Puangdownreong, "Parameter Identification of BLDC Motor Model Via Metaheuristic Optimization Techniques," Procedia Manuf. , vol. 4, 2015, doi: 10.1016/j.promfg.2015.11.047.

\section{AUTHOR(S) BIOGRAPHY}

Pawenary is a Lecturer in Electrical Technology at PLN Technology Institute. Pawenary completed his D1 in 1999 at Sriwijaya State Polytechnic. Bachelor's degree at Sriwijaya University in 2001. Master's degree obtained pawenary at the University of Indonesia in 2011. Pawenanry completed his Doctorate at The State University of Jakarta in 2020. 